\title{
Medical Experts and Agnotology in the Fumes Controversy of the Huelva Copper Mines (1888-1890)
}

\author{
XIMO GUILLEM-LLOBAT * \\ University of Valencia, López Piñero Institute for the History of Medicine and Science, \\ Universitat de València, Plaça Cisneros 4, 46003 València, Spain
}

\begin{abstract}
Huelva's copper mines (Spain) have been active for centuries but in the second half of the nineteenth century extractive activities in Riotinto, Tharsis, and other mines in the region were intensified in order to reach world leadership. The method used in these mines for copper extraction from low grade ores generated continuous emissions of fumes that were extremely controversial. The inhabitants had complained about the fumes for decades but as activity intensified so did complaints. The killing of anti-fumes demonstrators in 1888 led to the passing of a Royal Decree banning the open-air roasting of ore and to the drafting of numerous reports on the hazards of the fumes. Major state and provincial medical institutions, as well as renowned hygienists and engineers, took part in the assessment, contributing to a scientific controversy especially rich in content. In my paper I will analyse the production and circulation of knowledge and ignorance about the impact of fumes on public health, as well as the role of medical experts and expertise in the controversy. The analysis will focus on the reports drafted between the 1888 ban and its 1890 repeal, and will show the changing nature of the expert assessment and the numerous paths followed by experts in producing ignorance. The paper will conclude by considering other stakeholders, who may shed some light on the reasons behind the performance of the medical experts.
\end{abstract}

Keywords: Expertise, Ignorance, Fumes, Public health, Riotinto, Royal Academy of Medicine

\footnotetext{
* Email address for correspondence: ximo.guillem@uv.es
}

This paper is the result of investigations funded by the research project 'La sanidad internacional y la transferencia de conocimiento científico en Europa 1900-1975' (Ministerio de Ciencia e Innovación - HAR201123233) directed by Professor Josep Lluís Barona. I presented drafts of this text at meetings held in Bergen, Aixen-Provence, Munich and Ciudad Real and benefited from the comments raised by the participants. In its early stages, the paper also benefited from a research stay at the University of Exeter and the comments raised by Professor Joseph Melling. I am also grateful for the help I received from Ignacio Díaz-Delgado (Real Academia Nacional de Medicina), Carolin Schmitz (Ingenio - CSIC/UPV) and Juan Manuel Pérez López (Archivo historico minero de Riotinto). 


\section{Introduction}

1888 is remembered in Huelva (Spain) as the 'Año de los Tiros' [the Year of the Shooting]. On 4 February 1888, citizens and farmers of Zalamea del Real and other neighbouring villages demonstrated against the fumes from the copper mines in the area. They marched from Zalamea del Real to Riotinto. Before entering the village, they were joined by the miners of Riotinto, who had been on strike since February 1. Farmers protested against the fumes on account of their damaging effect on agriculture and public health, while the miners' claims included references to the smoke, because under certain circumstances it forced them to stop working and subsequently lose their daily wages. ${ }^{1}$ At the village's main square, the demonstration ended with speeches by their respective leaders followed by fierce repression from the Regimiento de Pavia of the Spanish infantry, with a toll of numerous protesters seriously injured and dozens dead. This incident was a major turning point in the long controversy about the fumes in Huelva and has been considered a key event in the origin of environmental campaigning in Spain. ${ }^{2}$

The 1888 killing led to the passing of a Royal Decree banning the open-air roasting of ore (RD of 29 February 1888), to the militarisation of the region, and to numerous reports on the hazards of the fumes from the Huelva copper mines. Major state and provincial medical institutions, as well as renowned hygienists and engineers, took part in the assessment, contributing to a scientific controversy particularly rich in content. On 18 December 1890 a new ruling repealed the Royal Decree and its ban, the previous legal situation being resumed. This paper analyses the production and circulation of knowledge and ignorance about the impact of the fumes on public health, as well as the role of experts and expertise in the controversy. ${ }^{3}$ The paper begins with a short presentation of the case and continues with the analysis of the medical expertise.

The region of Huelva in south-west Spain has been a prominent source of copper for centuries. Many authors have analysed the large-scale mining activity in the area in very different ways. The mines of Tharsis and Riotinto have drawn special attention and have been studied from a political, social, environmental and largely economic perspective. British historians such as S.G Checkland and Charles Harvey authored monographs, focused on the mines of Tharsis and Riotinto respectively, several decades ago. ${ }^{4}$ Since then, local historians have analysed these mines from very different viewpoints, including

\footnotetext{
${ }^{1}$ M.D. Ferrero Blanco, 'Los conflictos de febrero de 1888 en Riotinto: Distintas versiones de los hechos', Huelva en su Historia, 2 (2011), 603-23.

${ }^{2}$ Environmental popularisation books consider this conflict to be the first environmentalist protest in Spain. See, e.g., Joaquín Fernández, El ecologismo español (Madrid: Alianza, 1999).

3 The issue of air pollutants and public health has been considered in authoritative books reprinted in recent years, e.g. Peter Brimblecombe, The Big Smoke: A History of Air Pollution in London since Medieval Times (Oxford: Routledge, 2012) and Stephen Mosley, The Chimney of the World: A History of Smoke Pollution in Victorian and Edwardian Manchester (Oxford: Routledge, 2008), as well as in more recent books, e.g. J.R. Fleming and A. Johnson (eds), Toxic Airs: Body, Place, Planet in Historical Perspective (Pittsburgh, PA: University of Pittsburgh Press, 2014). For a more specific focus on fumes from mines, see also, e.g. J.D. Wirth, Smelter Smoke in North America: The Politics of Transborder Pollution (Lawrence, KS: University Press of Kansas, 2000).

${ }^{4}$ S.G. Checkland, The Mines of Tharsis: Roman, French and British Enterprise in Spain (Glasgow: Allen \& Unwin, 1967) and Ch. E. Harvey, The Rio Tinto Company: An Economic History of a Leading International Mining Concern 1873-1954 (Penzance: Alison Hodge, 1981). See, as well, D. Avery, Not on Queen Victoria's Birthday: The story of the Rio Tinto mines (London: Collins, 1974).
} 
those dealing with the controversy on the impact of fumes. ${ }^{5}$ However, the contribution that medical and scientific experts made to the controversy has been scantily considered, and the actual assessment practices of experts have usually been black-boxed.

The fumes were caused by the procedure applied to the low-grade ores extracted from the mines (with ore grades that in many cases did not exceed $2 \%$ ). This ore was abundantly available in the vicinity of the mine and was burnt for four to six months to obtain a higher concentration of copper. ${ }^{6}$ The ore was crushed and piled up into enormous heaps called teleras, where it was mixed with wood and substances like sodium chloride, and slowly burnt to remove the sulphur content. After calcination, a soluble copper salt was produced and transferred to cementation pools from which copper was recovered. This copper could then be marketed, but the procedure generated continuous fumes that were extremely controversial.

The mines of Riotinto and Tharsis, among others, had been active for centuries. The inhabitants of the region had complained about the fumes of the teleras for decades ${ }^{7}$ but it was not until the late nineteenth century that the fumes controversies saw a turning point, mainly prompted by changes in the Riotinto mines. In 1873, an Anglo-German consortium founded the Rio Tinto Company Limited and bought the mines from the Spanish state. Under the new company, the mines became more productive, ranking high in the world copper market. To reach such a leading position, extractive activities in Riotinto were intensified, thus further aggravating fume-related problems. ${ }^{8}$

Growing emissions of fumes in Riotinto added to increased emissions in nearby mines, such as Tharsis, which had intensified its activity a few years earlier with the arrival of French and British entrepreneurs. ${ }^{9}$ The new context gave way to escalating complaints and campaigns, and these resulted in the march of 4 February 1888. After the killing of the demonstrators, the Spanish Health Council (Consejo de Sanidad del Reino) drafted the report which led to the ban on open-air ore roasting. ${ }^{10}$ This opinion became a starting point for further reports, produced over the following two years. These reports make up the main object of analysis in my paper.

I have been able to identify strong links among several of the most relevant documents. Numerous shared quotations and important coincidences in the structure and the

\footnotetext{
${ }^{5}$ See, e.g., M.D. Ferrero Blanco, Capitalismo minero y resistencia rural en el suroeste andaluz: Riotinto, 18731900 (Huelva: Publicaciones de la Universidad de Huelva, 1999); C. Arenas Posadas, Empresas, mercados, mina y mineros: Rio Tinto (1873-1936) (Huelva: Publicaciones de la Universidad de Huelva, 1999); J.D. Pérez Cebada, Tierra devastada: Historia de la contaminación minera (Madrid: Sintesis, 2014); M. Flores Caballero, La venta de las minas de Riotinto (Huelva: Instituto de Estudios Onubenses, 1981); L. Gil Varón, Minería y migraciones: Riotinto 1873-1973 (Córdoba: Sociedad Cooperativa Industrial Tipografía Católica, 1984); J.M. Pérez López, Las calcinaciones al aire libre: Las teleras: Los conflictos sociales de febrero de 1888: Causas y consecuencias (Huelva: Fundación Riotinto, 1994).

${ }^{6}$ D. Cortázar, La mina de Rio Tinto y sus calcinaciones: Discurso pronunciado en la conferencia del 26 de enero de 1888 celebrada en el Ateneo de Madrid (Madrid: Manuel G. Hernández, 1888).

${ }^{7}$ Juan Diego Pérez Cebada argues, for instance, that the impact of fumes on nearby orchards had given rise to increasing complaints that eventually led to the first compensation file in Spain, in 1847 (J.D. Pérez Cebada, 'Minería del cobre y contaminación atmosférica: Estrategias empresariales en las cuencas de Swansea, Huelva y Montana', Revista de Historia Industrial, 16 (1999), 45-66).

${ }^{8}$ The intensification of extractive activities was progressive but conspicuous, as stated by Arenas Posadas and other authors. For instance, in 1890 the amount of copper ore extracted by the company was twice that extracted in 1880. Arenas Posadas, op. cit. (note 5), 64.

${ }^{9}$ Checkland, op. cit. (note 4).

${ }^{10}$ Dictamen del Consejo Supremo de Sanidad del Reino, sobre si debe o no considerarse como insalubre el procedimiento de calcinación al aire libre que emplean las empresas mineras en la Provincia de Huelva (Sevilla: A. Izquierdo y sob., 1888).
} 
information included are clear signs of the strength of such links. For every major issue considered in the reports, my analysis will confront the arguments raised by both detractors and supporters of the 1888 ban. I will consider how knowledge and ignorance were produced and circulated and, in so doing, I will touch upon the growing literature on agnotology. ${ }^{11}$

Recent historiography on toxicants and regulation has also developed other approaches that could give further insight into the Huelva fumes controversy. This is the case with the concept of industrial hazard regimes formulated by Christopher Sellers and Joseph Melling as 'those arrangements, formal as well as informal, by which public bodies, private interest groups and civic parties mobilize to comprehend, define and deal with the dangers connected with a particular form of production'. ${ }^{12}$ My study will keep this perspective in mind and will return to it, more explicitly, in the conclusion.

Among the main reports by medical experts which will be analysed, I include two that were written in 1888 before and right after the ban on calcination. ${ }^{13}$ I will also consider the reports produced at another key moment in the controversy, in the first half of 1890. This period was marked by the government's request for a new survey by the Royal Academy of Medicine; from this period I will consider numerous handwritten reports by members of the Royal Academy, ${ }^{14}$ the published reports by academician Ángel Pulido, and the one by academician Vicente Martín de Argenta and the member of the Spanish Hygiene Society José Martínez Pacheco. ${ }^{15}$ The latter reports, which supported a repeal of the ban, will be compared to other contemporary reports with opposing views, such as that by the physicians working for the Provincial Health Board, ${ }^{16}$ and that promoted by the Liga Antihumista [Anti-Fumes League]. ${ }^{17}$

${ }^{11}$ See, e.g., R.N. Proctor and L. Schiebinger (eds), Agnotology: The Making and Unmaking of Ignorance (Stanford, CA: Stanford University Press, 2008); M. Gross, Ignorance and Surprise (Cambridge, MA: MIT Press, 2010); L. McGoey, 'Strategic Unknowns: Towards a Sociology of Ignorance', Economy \& Society, special issue, 41 (2012); M. Smithson, Ignorance and Uncertainty: Emerging Paradigms (New York: Springer, 1989). The problem of uncertainty in science has also been very relevant to the development of frameworks such as that of post-normal science: see S.O. Funtowicz and J.R. Ravetz, 'Three types of risk assessment and the emergence of postnormal science', in S. Krimsky and D. Golding (eds), Social Theories of Risk (Westport, CT: Greenwood, 1992), 251-273.

12 C. Sellers and J. Melling, 'Towards a Transnational Industrial-Hazard History: Charting the Circulation of Workplace Dangers, Debates and Expertise', British Journal for the History of Science, 45 (2012), 401-24.

13 Dictamen del Consejo Supremo de Sanidad del Reino, op. cit. (note 10); H. Rodríguez Pinilla, Los Humos de Huelva ante la Higiene Pública (Madrid: G. Juste, 1889).

14 [Sobre las calcinaciones de la compañía minera de Riotinto], 1889-1890, Biblioteca de la Real Academia Nacional de la Medicina.

15 A. Pulido Fernández, Las calcinaciones de Huelva (Problema de salubridad) (Madrid: Enrique Teodoro, 1890); A. Pulido Fernández, Más sobre las calcinaciones de Huelva (Problema de salubridad) (Madrid: EnriqueTeodoro, 1890); V. Martín de Argenta and J. Martínez Pacheco, Los minerales de cobre y Riotinto (Madrid: Escuela Tipográfica del Hospicio, 1890).

16 G. Coto et al., Los humos de Rio-Tinto y su influencia en la salud pública y la vegetación (Madrid: El Resumen, 1890) and Exposición a s.m la reina regente de la liga contra las calcinaciones de Huelva: Asociación de 30 pueblos perjudicados de esta provincia y uno de la de Sevilla (Madrid: Fernando Cao y Domingo de Val, 1890). ${ }^{17}$ Farmers and other inhabitants of the region played an active role in the controversy through the Liga Antihumista. This association was headed by rich and influential local landowners and lobbied against the fumes caused by the extraction of copper and its serious impact on local agriculture. The group was led by José María Ordóñez Rincón, an important landowner from Higuera de la Sierra and a provincial representative in Parliament. It also had great support from highly influential people such as José Lorenzo Serrano, who was Ordóñez Rincón's father-in-law and known as the 'Great Overlord of Zalamea' (Ferrero Blanco, op. cit. (note 5)); Zalamea being the main municipality in the region where the mines of Riotinto were located. 


\section{The Royal Academy of Medicine}

In response to the lobbying action of the Rio Tinto Company, the Spanish government contacted the Royal Academy of Medicine in their search for a new expert evaluation. The Madrid Academy had operated with a 'national' identity since the 1860s, acting as one of the main governmental and judicial advisory organs. ${ }^{18}$ The Academy apparently stood as the ultimate source of expertise in medical controversies. When it was approached, previous reports by physicians, provincial health boards or municipal laboratories were already available; the members of the Academy used them as a basis for their final statement. They did not usually develop original research, but something seemed to be different in the case of the fumes controversy.

In response to the first request, a report dated November 1889 by the pharmacologist and academician Gabriel de la Puerta recommended that a special commission of the Academy should visit the Riotinto mines in order to respond to the government. ${ }^{19}$ The authorities had requested information on the maximum acceptable doses of sulphurous gases that the atmosphere could take and on the detection methods to be applied in controls. However, the Academy stressed the difficulty of addressing the first question and the need to carry out a special on-site study to be able to give an answer. The government was not pleased with this statement and at the end of December 1889 they reiterated their request for an official report by the Royal Academy. On 8 January 1890, a special commission including three members of the Academy (Manuel Iglesias, Mariano Carretero and Ángel Pulido) was set up, and on 17 January the commission finally submitted the requested report. ${ }^{20}$ The document gave answers to the second question (detection methods) and, for the first one, it established a theoretical threshold of five per cent, based on Ludwig Hirt's data to which I shall refer later. They argued that lower proportions of sulphurous gases would not pose any significant risks to the population. The in situ study was still to be conducted.

A few days after the report had been submitted, Mr Bushell, the representative of Rio Tinto Company in Madrid, invited the members of the Academy to visit the mines. On 14 February 1890, a party of fourteen academicians joined by experts from the Spanish Health Council and the Spanish Hygiene Society, as well as numerous military and political representatives, travelled from Madrid to Huelva to evaluate the impact of the fumes from the copper mines in the region. In their four day expedition, the main sites of the controversy were visited, and local miners, physicians and citizens were interviewed. ${ }^{21}$

The party visited Calañas and the mine of La Zarza on the first day. The programme for the second day included a visit to the Riotinto mines, and on the third one they inspected the villages of Riotinto and Nerva. Relevant data were collected and, once back in Madrid, chemical, physiological and clinical analyses were carried out. Ángel Pulido was the most disciplined academician. Having been involved in the special commission of the Academy, he became a major stakeholder in the controversy. In fact, he published a monograph on the fumes in Huelva within a month from the trip. The monograph was sent to the members of the Academy and arguably had a strong influence on them. They had not yet

\footnotetext{
${ }^{18}$ L.S. Granjel, Historia de la Real Academia Nacional de Medicina (Madrid: RANM (Real Academia Nacional de Medicina), 2006).

19 G. de la Puerta, Informe Sección de Higiene de 28 de Noviembre de 1889 [Sobre las calcinaciones de la compañia minera de Riotinto], Biblioteca Real Academia Nacional de Medicina.

${ }^{20}$ M. Iglesias, M. Carretero and A. Pulido, Informe de la Comisión referente a las minas de Riotinto del 17 de Enero de 1890 [Sobre las calcinaciones de la compañia minera de Riotinto], Biblioteca Real Academia Nacional de Medicina.

${ }^{21}$ Pulido Fernández, Las calcinaciones de Huelva, op. cit. (note 15).
} 
begun discussing on the issue; some of them even said they were still recovering from the visit when they received the book and were asked to share their opinion with the author. The book also triggered an interesting debate with the physicians of the Provincial Health Board in Huelva and can be globally considered a key document for the understanding of the new stance taken by Spanish medical expertise.

Shortly after the expedition to Huelva, the Spanish government asked the Academy for a report again hoping they would now have the necessary data. Discussions were then reopened and finally settled a few months later, with the approval of a report that would be key to the December 1890 repeal of the ban on open-air roasting of ore.

\section{Contemporary Conflicts over Copper Fumes}

The mining region of Huelva experienced the effects of copper fumes with special virulence due to the intensity of extraction activities and calcination. Other regions in the world faced similar problems and, in all cases, people raised analogous controversies. ${ }^{22}$ Interestingly, several of these regions were well connected to Riotinto during the studied period. Conflict emerged, for instance, in a Rio Tinto Company factory in L'Estaque in Marseilles, although the main hazards in this case were apparently linked to water pollution and its effects on fisheries. ${ }^{23}$ In St Denis, the projected production of copper and sulphuric acid using pyrite from Riotinto as a raw material led to a huge controversy. The engineer B. Sincholle, in charge of the report of the Comité de Défense des Riverains de la Seine, concluded that the arsenical substances and other pollutants that would be produced would constitute a serious hazard to the river and those living in the area. ${ }^{24}$ The connections of these cases with the Huelva controversy are obvious but interestingly no relevant references to them were included in the Royal Academy debates or in the expert reports on the fumes in Huelva.

In California, Montana and Utah (USA), several copper mines intensified production during the period, and controversy about fumes was also present there. The links of these mines with Huelva were not initially very important but at the turn of the century several engineers who had been trained in those mines arrived in Riotinto and other neighbouring mining sites. ${ }^{25}$ Yet, to handle the fumes issue, it was Swansea, in Wales, that seemed to be a continuous source of information. By the mid-nineteenth century South Wales was regarded as the world's leading centre for industrial metallurgy and this was especially true for copper. The ore first arrived in Wales from Cornwall and later from Huelva, among other sources, and it was processed in the copper smelters there. Fumes were released into the atmosphere in huge quantities, which aroused heated debates. ${ }^{26}$ In Wales, the Rio Tinto Company got involved in the controversy owing to its works in Cwmavon. ${ }^{27}$ These works had serious effects on the farms of Miss Emily Talbot and compensation was demanded. It was not an isolated case. There had been conflicts over 'copper-smoke' in Swansea for

\footnotetext{
22 Pérez Cebada, op. cit. (note 5).

${ }^{23}$ D. Faget, 'Stratégies de communication et émergence de nouvelles expertises: les pollutions industrielles de l'usine marseillaise Rio Tinto à l'Estaque (1882-1914)', in L. Centemeri and X. Daumalin (eds), Pollutions industrielles et espaces méditerranéens (XVIIIe-XXIe siècle) (Aix-en-Provence: Karthala-MMSH, 2015).

${ }^{24}$ B. Sincholle, Protestation contre l'établissement Saint-Denis d'une usine pour la production du cuivre et de l'acide sulfurique (Paris: Chaix, 1883) and Pérez Cebada, op. cit. (note 5).

25 Arenas Posadas, op. cit. (note 5).

${ }^{26}$ Historians such as Edmund Newell have been most prolific in dealing with the environmental impact of copper metallurgy in South Wales.

${ }^{27}$ E. Newell and S. Watts, 'The Environmental Impact of Industrialization in South Wales in the Nineteenth Century: "Copper Smoke" and the Llanelli Copper Company', Environment and History, 2 (1996), 309-36.
} 
a long time, and the main mines in Huelva (Tharsis and Riotinto) were arguably aware of them, as most of their senior employees were British. ${ }^{28}$ Despite being well-known cases, they were poorly represented in the debates, as we will see in the next few paragraphs.

\section{Deconstructing Expert Assessment on the Fumes Controversy}

Overall, the reports written by medical experts between 1888 and 1890 provide several important issues for discussion. This paper addresses the main arguments (metallurgical, chemical, physiological or demographic) raised in the reports and analyses their soundness as statements and their contribution to knowledge or/and ignorance.

\section{Non-Medical Approaches}

Considering that the authors of the reports were medical experts (mainly physicians and pharmacists), attention must be paid to the numerous non-medical approaches included. For example, the region's mining history was described by Martín de Argenta and Martínez Pacheco and also in Rodríguez Pinilla's report. Its mineral content was analysed by Fernández-Caro and again by Pinilla. ${ }^{29}$ Included as introductory notes, these subjects were covered without proven expertise. Although they did not really contribute to the overall influence exerted by the reports, it is a noteworthy aspect, for two reasons: because it can be considered a first sign of the problem of extension, ${ }^{30}$, with medical experts developing arguments beyond their expertise; and because it somehow evidences the circulation of knowledge beyond disciplinary borders. ${ }^{31}$ The arguments and cases used by medical experts did not substantially differ from those of other professionals such as engineers. This can be seen, for instance, in the speech published by the engineer Daniel de Cortázar. ${ }^{32}$

The reports contained other non-medical issues that could play a more relevant role when presenting them as solid grounds for either the banning or the authorisation of the fumes. Metallurgical issues were included in many of the reports, for instance. Those against the teleras ban justified their use by stressing the inexistence of alternative extraction methods for pyrite mines like the ones in Huelva. ${ }^{33}$ References to alternative methods were included in several reports, but they were shallow and designated unswervingly as ineffective and thus non-feasible. In their report, Martín de Argenta and Martínez Pacheco explicitly state that science had no alternative process for the ore type found in Huelva and therefore the use of the teleras method could not be dismissed.

The issue could have been approached from a very different perspective. In their 1890 report, the members of the Liga contra las calcinaciones de Huelva [League against Calcination in Huelva] stated that at least two regulations passed in 1849 and 1863 obliged

\footnotetext{
${ }^{28}$ Arenas Posadas (op. cit. (note 5)) refers to two special agents from the Rio Tinto Co. who were mainly involved in locating and hiring specialists from Wales, Cornwall and Devon: Thomas Angove (working from 1875 to 1884) and Moses Bawden (working from 1884 to 1906).

${ }^{29}$ A. Fernández-Caro, Informe acerca de las calcinaciones de minerales de cobre de Junio de 1890 [Sobre las calcinaciones de la compañía minera de Riotinto], Biblioteca Real Academia Nacional de Medicina.

${ }^{30}$ H. Collins and R. Evans, Rethinking Expertise (Chicago, IL: The University of Chicago Press, 2007).

${ }^{31}$ In his study of smelting technologies in Montana, Fredric Quivik identified the existence of interdisciplinary committees dealing with smoke-related issues. These committees option to solve the problem of of the existence of such committees in Riotinto for the period considered in this paper. See Fredric L. Quivik, 'Smoke and Tailings: An Environmental History of Copper Smelting Technologies in Montana, 1880-1930' (unpublished $\mathrm{PhD}$ dissertation: University of Pennsylvania, 1998).

32 Cortázar, op. cit. (note 6).

${ }^{33}$ Martín de Argenta and Martínez Pacheco, op. cit. (note 15); Rodríguez Pinilla, op. cit. (note 13).
} 
metallurgical works to use condensation chambers with long horizontal projections. ${ }^{34}$ The Royal Order of 21 December 1863 had also been considered in reports against the fumes drafted in $1878 .{ }^{35}$ Their authors claimed that this legislation applied to the coppermining industry and thus questioned the legality of teleras. However, the question of the applicability of these regulations did not really pervade the 1890 discussions. The reports produced at the Royal Academy did not address it, and they made no reference to the enforcement of similar laws in other countries either. ${ }^{36}$ No reference was made, for instance, to the long search for new technologies intended to reduce emissions of fumes in the copper smelters of South Wales. ${ }^{37}$ In Riotinto, these technologies were only introduced at the turn of the century following important changes in metallurgical methods (changes that were not prompted by public health concerns but by economic reasons, according to historians such as Carlos Arenas Posadas). Large chimneys, like the Chimenea Pirítica -159 meters high - were then built. ${ }^{38}$

The use of teleras was harshly criticised by the Liga: 'emplean el procedimiento metalúrgico más primitivo, ya desechado por la ciencia que reconoce otros mejores, y prohibido en el mundo civilizado por leyes especiales que lo declaran nocivo a todo los organismos' [they use the most primitive metallurgical method, one rejected by a science that acknowledges the existence of better ones, a method banned in the civilised world through special laws that consider it noxious to all organisms]. ${ }^{39}$

The report by the Liga argued that there were many alternatives to this method, some of them were even more economical. The most frequently quoted case in defending these alternatives was that of the mines of Santo Domingo (in Portugal, but also part of the Iberian Pyrite Belt and near the mines of Huelva). ${ }^{40}$ In these mines the conflict over fumes had forced a ban on the open-air roasting of ores resulting in the reintroduction of spontaneous or atmospheric roasting (or spontaneous creation of sulphate salts of copper). The Santo Domingo mines had succeeded in the application of this method and, at the height of the fumes conflict, other major mines in the area made similar changes in metallurgical methods. That was the case in Tharsis, where calcination was drastically reduced by the late 1880 s. $^{41}$

Interestingly, after visiting the mines of La Zarza and Tharsis, Pulido and the other members of the Academy reported on their personal experience of inhaling fumes.

\footnotetext{
${ }^{34}$ Exposición a s.m la reina regente, op. cit. (note 16).

35 Exposiciones al Gobierno de S. M. sobre los daños que ocasionan a la salud pública y a la Agricultura los humos de las calcinaciones de los minerales cobrizos (Huelva: Mendoza, 1878).

${ }^{36}$ I have only found a short note on the inapplicability of British legislation on smoke to the teleras fumes. It was included in the report by Martín de Argenta and Martínez Pacheco. However, the text refers to legislation in a very unspecific way, without substantial proof and in contrast to numerous quotations from contemporary authors that stressed the illegal character of the method within British law.

37 The historian Edmund Newell, among others, has dealt with the alternative methods applied by Vivian and Sons and other British smelters since the beginning of the 19th century.

${ }^{38}$ Pérez Cebada, op. cit. (note 5).

${ }^{39}$ Exposición a s.m la reina regente, op. cit. (note 16), 5-6.

${ }^{40}$ Some historians have also identified several initiatives that had been put forward by the directors of the Riotinto Company. The managers sought to evaluate the implementation of alternative methods to that of the teleras. These initiatives would have taken place in 1878, but did not prove successful. Therefore, they did not lead to any relevant change in the metallurgical works in Riotinto: see P. Garrido Camacho and J.D. Pérez Cebada 'La primera campaña mediática sobre contaminación en España', in P.E. Guimares and J.D. Pérez Cebada (eds), Conflitos Ambientais na Indústria Mineira e Metalúrgica: O passado e o presente (Rio de Janeiro: CETEM/MCTIC, 2016), 269-290.

${ }^{41}$ Checkland, op. cit. (note 4).
} 
However, in so doing, they did not say a word about the reduction in emissions in both mines following the progressive change of the metallurgical method. ${ }^{42}$ In this case, the medical experts' lack of expertise or their 'selective inattention' and conscious construction of ignorance had more serious consequences, as it became a relevant point in opting for open-air roasting. ${ }^{43}$

Another non-medical issue in the reports of many physicians and pharmacists intended to end the conflict between humistas and anti-humistas was that of market and economic profitability. In most reports, wealth in the region was directly linked to copper mining and open-air roasting. This matter, however, was not always openly dealt with. For instance, in his report Rodríguez Pinilla says that he would not engage in economic analyses but he then devotes a paragraph to concluding that the region was better off thanks to copper mining. This ambiguous manoeuvre was probably prompted by the detachment from economic matters that scientists usually displayed, yet they implicitly incorporated economic issues into their evaluation work. Concurrence with the points made by engineers such as Cortázar may have implied, once more, that communication had occurred, but communication is arguably more opaque than ever in this particular case.

The weight of non-medical issues in a great many reports by pharmacists and physicians was, therefore, greater than we could expect. In the report written by Martín de Argenta and Martínez Pacheco, more pages were devoted to these issues than to medical ones. But public health was always made room for in the reports; and it was approached from two main perspectives: chemical and demographic analyses.

\section{The Chemical-Physiological Approach}

With the expansion of experimental hygiene, resorting to chemistry in public health matters became more and more common in the late nineteenth century. This trend was clear, for instance, with the establishment of municipal laboratories throughout Europe from the late 1870s and was also increasingly noticeable in expert assessment on other topics such as food safety. The reports we are considering always referred to chemical reactions in the roasting of ores and to the chemical composition of the fumes. In fact, this was implicitly requested by the government when they asked about acceptable levels of sulphurous acid (sulphur dioxide) in the air and the most suitable method for control.

The immediate response of experts as regards acceptable levels was to stress the enormous variability under open-air conditions. Analyses should consider air composition at different distances and with diverse weather conditions, etc. Conclusions from studies in enclosed areas could not be extrapolated. ${ }^{44}$ However, these statements were not followed by active measures intended to analyse air composition in the Riotinto region in all its variations. The complexities expressed in the first reports of the members of the Royal Academy were dismissed in the final discussion, after the expedition to Huelva. Internal contradictions can now be easily identified when comparing reports; at the time, they were reported by members of the Academy such as Santiago de la Villa and Manuel Iglesias in

\footnotetext{
42 Pulido Fernández, Las calcinaciones de Huelva, op. cit. (note 15); Martín de Argenta and Martínez Pacheco, op. cit. (note 15).

${ }^{43}$ R. N. Proctor, 'Agnotology: a missing term to describe the cultural production of ignorance (and its study)', in R.N. Proctor and L. Schiebinger (eds), Agnotology: The Making and Unmaking of Ignorance (Stanford, CA: Stanford University Press, 2008), 1-33.

${ }^{44}$ G. de la Puerta, Informe Sección de Higiene de 28 de Noviembre de 1889 [Sobre las calcinaciones de la compañia minera de Riotinto], Biblioteca Real Academia Nacional de Medicina.
} 
their dissent with the first draft of the report by the Hygiene Section of the Academy. ${ }^{45}$ For example, Villa and Iglesias criticised the fact that the report stated there was no sulphurous acid (sulphur dioxide) outside the teleras camp in normal conditions. To make their point, Iglesias and Villa argued that observations should have been made in different seasons, with different meteorological conditions and taking into account the amount of burning ore and the number of active teleras. One may wonder if the simplified approach finally developed by the Academy was a valid path towards the construction of knowledge or otherwise ignorance.

Not many analyses were cited in the reports of the Royal Academy of Medicine. Available materials only include a brief reference to the analyses carried out by Gabriel de la Puerta, from the hygiene section of the Royal Academy of Medicine, and his son, at the base of and at a short distance from the teleras (50 or 100 metres depending on the report considered). Another member of the Academy, José Font y Martí, was asked to pick up a sample from a telera, probably in Tharsis, and analyse it in Madrid. There was no further news about the results of this analysis. In any case, samples were collected on a day with favourable environmental conditions, and low doses of sulphurous gases were detected. It was actually a rainy day (as can be grasped from Pulido's account). ${ }^{47}$

These analyses were intended to help argue in favour of the harmless nature of the fumes but they were clearly insufficient. The reports occasionally accounted for the lack of further analyses, alleging that failure to detect the characteristic smell of sulphurous acid (sulphur dioxide) rendered air analysis pointless. This was also criticised by Iglesias and Villa's in their minority report. They argued that current treatises on chemical analysis did not accept smell as a good approach to a qualitative analysis because this trait could be misleading in the presence of specific reagents. Finally, no answer was given to why the academicians who visited Riotinto did not carry out the systematic air composition analysis that considered the variations predicted by scholars. This was especially significant on this occasion because, although Academy members did not often complete their own experimental work in their assessment tasks, this time their insistence on the need for an in situ study suggested a different situation. Finally, the difference was rather minimal and consensus was built from very limited experimental work.

Regarding fume analysis, another relevant point was the tight focus on the one substance that seemed to prevail in all the reports and in the government requests. The substance to be identified and measured was always sulphurous acid (sulphur dioxide), while the action of other potentially noxious substances was ruled out from the beginning. The way this question was posed to the Academy obviously conditioned their answer. Its focus on sulphurous gases made other potential toxicants invisible, thus adding to ignorance about them. ${ }^{48}$ Moreover, the search for a standard of acceptable concentration levels for sulphurous gases also contributed to dismissing the many complexities raised in the discussions, yet it did not prevent the Academy from considering a possible five per cent limit, to which I shall refer later in analysing the physiological approach.

\footnotetext{
${ }^{45}$ M. Iglesias and S. de la Villa, Voto particular de los Sres. Iglesias y Villa en el expediente de las calcinaciones de Riotinto [Sobre las calcinaciones de la compañia minera de Riotinto], Biblioteca Real Academia Nacional de Medicina.

${ }^{47}$ Pulido Fernández, Más sobre las calcinaciones de Huelva, op. cit. (note 15).

48 This additional approach to the construction of ignorance has already been tackled by other scholars in analysing environmental controversies. See, e.g., S. Frickel and M. Edwards, 'Untangling ignorance in environmental risk assessment', in S. Boudia and N. Jas (eds), Powerless Science? Science and Politics in a Toxic World (New York: Berghahn, 2014), 215-33.
} 
From the additional elements which could constitute a serious public-health hazard, isolated references were made to arsenical and antimonial gases, hydrochloric acid and dust. The most relevant case was possibly that of arsenical gases. It was the only potential toxicant (apart from sulphurous gases) mentioned in most of the reports between 1888 and 1890. All authors admitted its existence but fume-tolerant reports (Rodríguez Pinilla, Pulido, and Fernández Caro, among others) always referred to an 1865 discussion in Paris at the Académie des Sciences about the prophylactic effects of sulphurous and arsenical gases against cholera. On one such occasion a Spanish engineer, Casiano del Prado, said that arsenical gases in Riotinto had only been detected with the Marsh test in such small amounts that they did not have any relevant toxic effects. This one case was enough for the above-mentioned medical experts to dismiss the potential action of arsenical emissions.

Despite the Spanish reports, arsenical toxicity was evaluated throughout the nineteenth century, tighter regulation being continually demanded. ${ }^{49}$ As for the role of arsenic in the health and environmental impact of smelter fumes, German authors such as Sussdorff (1855) and Haubner (1878) had already made important contributions, concluding that trees and grass in smelter districts were damaged by sulphur dioxide and sulphuric acid in the fumes, and also that the grass was rendered poisonous for horses and cattle as a result of the deposition of mineral poisons and specifically of arsenic. The work done by these and other authors was still quoted at the turn of the century by American experts like Harkins and Swain (1907 and 1908), when dealing with the effects of arsenic in smoke emanating from a copper smelter in Anaconda, Montana. ${ }^{50}$ The Spanish experts, however, did not consider these works in any way. At this level, one could again speculate on the lack of knowledge circulation or, more likely, on some kind of selective inattention leading to contributing to the conscious construction of ignorance. This selective inattention was not shared by all the authors involved in the controversy, though. The concern about arsenic was explicit in the reports of the Liga contra las calcinaciones and in the reports of the physicians linked to the Provincial Health Board of Huelva. ${ }^{51}$ However, the analysis of the reports has shown that, throughout the controversy, the members of the Academy did not offer new arguments to counteract the reports in favour of the ban; this is obvious for the potential role of arsenic, and it is even clearer in relation to dust or hydrochloric acid. While these toxicants were systematically considered in ban-favouring reports, they were rarely or never quoted in those against prohibition. Nevertheless, since the former would be left out in conceiving political and legislative action, they had no major influence on the settlement of the controversy.

The potential generation of hydrochloric acid in the teleras was taken into account by Provincial Health Board physicians, and by the two Academy members (Iglesias and Villa) who disagreed with the report of the Hygiene section drawn up by Fernández Caro. They argued that the presence of hydrochloric acid had to be evaluated for two main reasons: sodium chloride was added to the piles of roasting ore, and one of the members of the

\footnotetext{
${ }^{49}$ See, e.g., J. Whorton, The Arsenic Century: How Victorian Britain was Poisoned at Home, Work, and Play (Oxford: Oxford University Press, 2010) and J. Parascandola, King of Poisons: The History of Arsenic (Dulles, VA: Potomac Books, 2013).

${ }^{50}$ W.D. Harkins and R.E. Swain, 'Papers on Smelter Smoke: [First Paper] The Determination of Arsenic and Other Solid Constituents of Smelter Smoke, with a Study of the Effects of High Stacks and Large Condensing Flues', The Journal of the American Chemical Society, 29 (1907), 970-98; and W.D. Harkins and R.E. Swain, 'Papers on Smelter Smoke: [Second Paper] Arsenic in Vegetation Exposed to Smelter Smoke', The Journal of the American Chemical Society, 30 (1908), 915-46.

${ }^{51}$ See Exposición a s.m la reina regente, op. cit. (note 16), and Coto et al., op. cit. (note 16).
} 
Academy in their visit to the mines had noticed the smell of a substance that could have been hydrochloric acid. ${ }^{52}$ This acid was well-known for its toxicity; in fact, it was the main concern of alkali inspectors in Britain, for example. Yet, in their response to the minority report, the members of the hygiene section of the Academy did not say a word about it.

The hazards linked to the dust of copper mining were also raised in a number of reports supporting the teleras ban, including those of the Provincial Health Board and those submitted in 1878. In his second monograph, Ángel Pulido also admitted to the potential hazards of dust, but he connected dust to occupational hygiene exclusively, and dissociated it from public health. He was then able to argue that only public health was at stake and, consequently, there was no need to consider dust-related hazards.

Pulido's point on dust was arguably reinforced by two circumstances. Firstly, by describing it as an occupational hygiene problem, it became a minor issue. Spanish occupational medicine was basically inexistent until the passing of the compensation act on work accidents in January 1900 and subsequent laws and initiatives (such as the foundation of the Spanish Society of Occupational Medicine in 1934). Historians such as Alfredo Menéndez and Esteban Rodríguez-Ocaña have referred to a change in the conception of occupational safety starting in 1890 but, in any case, this incipient movement is subsequent to the period considered in this paper and initially focused on occupational accidents rather than on chronic poisoning. ${ }^{53}$ The chronology was basically in line with that of the international context. ${ }^{54}$ Secondly, although dust was identified as a hazard, regulations on the main dust-related diseases, such as silicosis or pneumonicosis, were only passed a few decades later. ${ }^{55}$

The division between public health and occupational hygiene could be tricky; in fact, it is still a major issue in current debates on environmental health. I am not able to elaborate on this matter at this point. However, we must note that the immediate consequence of the invocation of this divide was, once more, the concealment of a serious hazard considered in the growing literature on mining and health. ${ }^{56}$

The assessment of the Academy was thus exclusively focused on sulphurous gases, the gases examined by the experts visiting the mines; they did so through chemical and organoleptic tests. However, in order to answer the first question posed to the Royal Academy of Medicine, scholars had to consider the specific physiological consequences of inhaling this gas on the organism. In this regard, no original research was carried out by any of the authors of the reports. To establish this link, the 1888 report by the Royal Health Council and that by Rodríguez Pinilla referred to the works of a foreign scholar called Buschholtz; all the other reports used a different source in their

\footnotetext{
52 In an acidic medium, chloride could transform into hydrochloric acid.

53 A. Menéndez-Navarro and E. Rodríguez-Ocaña, "From "accident medicine" to "factory medicine": Spanish occupational medicine in the twentieth century', in A. Grieco; T. Carter and S. Iavicoli (eds), Origins of Occupational Health Associations in the World (Amsterdam: Elsevier Science, 2003); E. Rodríguez-Ocaña and A. Menéndez-Navarro, 'Salud, trabajo y medicina en la España de la legislación social, 1900-1939', Archivos de Prevención de Riesgos Laborales, 9 (2006), 81-88.

54 C. Sellers and J. Melling, Dangerous Trade: Histories of Industrial Hazard Across a Globalizing World (Philadelphia, PA: Temple University Press, 2012).

${ }^{55}$ M. Bloor, 'The South Wales Miners Federation, Miners' Lung and the Instrumental Use of Expertise, 19001950', Social Studies of Science, 30 (2000), 125-40.

56 Dust and health in mining have been central issues in numerous publications by authors such as Paul-André Rosental, Catherine Mills, Joseph Melling, David Rosner and Gerald Markowitz.
} 
attempt to link dose and health: Ludwig Hirt. ${ }^{57}$ Again, the sources for expert assessment seem weaker than expected, with no original empirical works and reference to only one study by an external author. Moreover, the quotation from Hirt was arguably misleading and, indeed, his work was contradictory to the requirements initially established by the Academy.

From Pulido's first monograph - the one effectively pre-circulated prior to open discussions at the Academy - we can conclude that Hirt was probably quoted in an indirect way through Henri Napias' Manuel d'Hygiène Industrielle. ${ }^{58}$ And if we consider Napias's interpretation of Hirt's study, we find an important omission in the reports of the impact of low concentrations of sulphurous acid on the organism. Quoting Hirt, Napias said in his book that high doses of sulphurous gases could be very noxious 'mais il suffrait de 1 a 4 pour 100 de gaz pour déterminer la toux, les maux de gorge, une irritation des premières voies qui long temps prolongée n'est pas sans quelque danger' [but 1 to 4 per cent of gas would be enough to determine a cough, a sore throat, irritation of the airways which, if prolonged, could be dangerous]. ${ }^{59}$ In the visit to Huelva, the analyses carried out by Gabriel de la Puerta detected up to 1.34-1.60 per cent of sulphurous gases, which was within the above-mentioned range. Yet, Pulido and his colleagues did not conclude that long exposure could be dangerous to local people in that situation. Instead, they considered this value proof of the innocuous nature of the fumes. This lack of attention to the problem of long exposure was criticised by the physicians of the Provincial Health Board of Huelva, but their criticism failed to change Pulido's mind. ${ }^{60}$

In a clearly biased reading of Hirt's results, the Academy reports claimed a five per cent threshold for sulphurous acid (sulphur dioxide). ${ }^{61}$ In the January report, explanations stopped at this point, and in their June papers the Academy members continued considering this reading of Hirt's results although they then included an additional element. They came to the conclusion that the doses described by Hirt as dangerous were not found at the mines and neighbouring areas, but then they also referred to the extremely variable composition of the atmosphere in open-air conditions and subsequently to the impossibility of establishing threshold levels. Instead of admitting the need for a more complicated procedure including systematic analyses in variable conditions, they just thought it to be an impossible approach, thus putting an end to the controversy associated with the first specific request made to the Royal Academy. ${ }^{62}$

Concerning the systematic use of Hirt's work, we must also note that his studies dealt with the physiological effects of sulphurous gases (and other toxicants) at different doses, but always in enclosed areas. In their letter of dissent, Santiago de la Villa and Manuel Iglesias criticised the Hygiene Section report for using these studies to assess the impact of the gases in open-air conditions. They stated that the Academy had initially considered

\footnotetext{
${ }^{57}$ Hirt was a German physician, a specialist in occupational health, who refers, in one of his main books, to the physiological consequences of different well-defined doses. For more information, see, e.g., C. Bury, " "Die Krankheiten der Arbeiter” (1871-1878) von Ludwig Hirt: Kritische Bemerkungen zur ersten Enzyklopädie der modernen Arbeitsmedizin in Deutschland' Dynamis 5 (1985), 404-416.

${ }^{58}$ H. Napias, Manuel d'Hygiène Industrielle (Paris: G. Masson, 1882).

59 Ibid., p. 108.

${ }^{60}$ Coto et al., op. cit. (note 16).

${ }^{61}$ M. Iglesias, M. Carretero and A. Pulido, Informe de la Comisión referente a las minas de Riotinto del 17 de Enero de 1890 [Sobre las calcinaciones de la compañia minera de Riotinto], Biblioteca Real Academia Nacional de Medicina.

62 A. Fernández-Caro, Informe acerca de las calcinaciones de minerals de cobre de Junio de 1890 [Sobre las calcinaciones de la compañia minera de Riotinto], Biblioteca Real Academia Nacional de Medicina.
} 
the use of results from studies in enclosed areas unacceptable for the evaluation of open-air conditions, but by mid-1890 they were still using them.

Citing Hirt was clearly insufficient to evaluate the impact of fumes on public health, and yet only a few minor references to other works were made. The topic being as controversial as it was in France, Britain or the USA, and with Spanish experts mainly contributing their interactional expertise, ${ }^{63}$ it is striking they did not delve into additional bibliography in which authors like the British Robert Angus Smith or the French Frédéric Le Play could have been quoted.

Frédéric Le Play travelled to Wales on three occasions and developed a five-year research project on Welsh mines before publishing, in 1848, his influential work: Description des procédés métallurgiques employés dans le pays de Galles pour la fabrication du cuivre et recherches sur l'état actuel et sur l'avenir probable de la production et du commerce de ce métal. His monograph described in detail the effects of metallurgical pollution on workers and residents in the Swansea Valley (a major international centre for copper mining). ${ }^{64}$

The work by Le Play had been well known to Spanish engineers since mid-century (as can be seen in papers published at the time in local specialised journals such as Revista Minera). And Le Play's contributions were referred to for years in international publications addressing the impact of the fumes from burning minerals on the environment or health (e.g. John Percy's Metallurgy). ${ }^{65}$ But the scholars involved in the Riotinto controversy did not refer to this bibliography in any significant way.

By mid-century, Robert Angus Smith was also a renowned author on the subject of smoke. Well-known for his work as an alkali inspector and for coining the term 'acid rain', he was also the author of a report focused on the air of mines, written in $1864 .{ }^{66}$ Certainly, in his position as alkali inspector his main concern was the effect of fumes on property and not on public health. However, his individual contributions to improved smoke analysis, as well as his involvement since 1874 in the implementation of a revised Alkali Act which included sulphurous acid (sulphur dioxide) other than that released in the combustion of coal, could have been relevant incentives to considering his works in the Huelva discussions. Instead, and despite the many references to British smoke pollution in Pulido's reports, they were completely overlooked.

Scholars supporting the teleras method seemed to prefer an arguably secondary author who had addressed the fumes issue in Swansea, Thomas Williams. Williams was quite successful in disseminating a statement already made by other local medical experts such as William Bevan. ${ }^{67}$ They argued that copper fumes were indeed beneficial to inhabitants owing to their prophylactic action against contagious diseases. Williams' report was published in 1854 and it was still quoted several decades later in reports by Pulido, Martín de Argenta and Martínez Pacheco, as well as by engineer Cortázar. The potential beneficial

${ }^{63}$ Collins and Evans, op. cit. (note 30).

${ }^{64}$ F. Le Play, Description des procédés métallurgiques employés dans le pays de Galles pour la fabrication du cuivre et recherches sur l'état actuel et sur l'avenir probable de la production et du commerce de ce métal (Paris: Carilian-Goeury et Dalmont, 1848).

65 J. Percy, Metallurgy: The Art of Extracting Metals from the Ores, and Adapting them to Various Purposes of Manufacture (London: J. Murray, 1861).

${ }^{66}$ P. Reed, Acid Rain and the Rise of the Environmental Chemist in Nineteenth-Century Britain: The Life and Works of Robert Angus Smith (Farnham: Ashgate, 2014).

${ }^{67}$ E. Newell, 'Atmospheric Pollution and the British Copper Industry, 1690-1920', Technology and Culture, 38 (1997), 655-89. 
effects of the gases were obviously criticised by the scholars who were against the teleras, like the physicians of the Provincial Health Board in Huelva. In the end, advocates insisted more on the innocuous nature of fumes than on their beneficial effects. Regardless of the veracity of the argument, with such a differentiated flow of knowledge, the idea of selective inattention is further reinforced.

Concerning the physiological action of the fumes, it must be noted that although the approach was mainly theoretical or based on a limited number of general studies (not specific to the copper mines of Huelva) by international scholars, the experiences of the Academy members who visited the mines were also considered. In this respect, the most classical clinical and organoleptic approaches of physicians were also employed. For instance, Rodríguez Pinilla described the symptoms he had in his visit to the mines and when walking around the teleras. He argued that individuals used to breathing the fumes did not have the same symptoms and that these disappeared once out of direct exposure. Ángel Pulido also referred to their innocuous nature with similar arguments (workers seemed happy and strong; one could always breathe fine if not facing the wind, etc.). He also said that, having shown an interest in meeting sick people in Riotinto, he had not found a single case that could be attributed to the fumes. However, Pulido overlooked the fact that, Riotinto being a sort of corporate village, ${ }^{68}$ the pressure on citizens was bound to be very strong: they arguably did not feel free to approach the doctors and share their experiences with them, as this type of information could be understood as criticism of the Rio Tinto Company (the company had full control on labour, commerce, health, etc.). A partial solution to this bias could have been found in the proposal of the physicians of the Provincial Health Board. They invited the members of the expedition to visit the Provincial Hospital in Huelva, but they declined their invitation, missing the opportunity to include this more impartial source of information in their assessment. This loss of information was heavily criticised. ${ }^{69}$

Finally, in relation to the contributions of medical experts towards defining an acceptable dose of sulphurous gases through chemical and organoleptic approaches to air quality as well as experimental and clinical approaches to health, reference must be made to a major constraint. None of the aforementioned studies dealt with the manta. Under specific atmospheric conditions, ${ }^{70}$ fumes concentrated in a particular way, and most medical experts agreed that the impact on nature and public health could then be much greater. ${ }^{71}$ On manta days, a thick layer of fumes covered the area next to the mines and workers had to leave.

Despite being pinpointed as a major issue, the manta was not analysed. In the main expedition to Huelva, the participants did not experience the phenomenon. Although Pulido did say he was unsure whether he had been exposed to it, the weather conditions he described in his report were incompatible with the manta. Also funded by the Rio Tinto

\footnotetext{
${ }^{68}$ Arenas Posadas has also referred to this issue on several occasions, noting that 'Riotinto era un trozo de España donde la ley, las convenciones sociales y las instituciones estaban controladas y puestas al servicio de la Compañia británica' [Riotinto was a part of Spain in which the law, social standards and institutions were controlled by the British Company] (Arenas Posadas, op. cit. (note 5), 209).

${ }^{69}$ Coto et al., op. cit. (note 16).

70 The manta would appear in calm and cold days with high humidity and, although not noted in contemporary reports, probably with high atmospheric pressures.

${ }^{71}$ On the hazards of the manta, different nuances can be found in specific reports. For instance, the special commission of the Academy stated in its report of 17 January 1890 that the risk of the manta was more 'illusory than real'. Nevertheless, there was general consensus among other reports on the special interest that this atmospheric phenomenon had in establishing the real impact of fumes.
} 
Company, a second smaller expedition included the Academy member Eusebio Castelo. Manta conditions were apparently present this time but they were not analysed and, as a consequence, they did not have any influence on the discussions on fume hazards at the Academy.

The only chemical analyses mentioned in the reports were not completed under manta conditions, and the only references to the composition of the manta were deduced from those near the teleras. The report by Fernández Caro - from the hygiene section of the Academy - concluded that the composition of mantas could not exceed the 1.6 per cent sulphurous acid detected at the teleras. This deduction was introduced by referring to an 'authorised assumption' and then followed by the phrase 'chemistry had proved it'. This blatant contradiction was explicitly criticised by Santiago de la Villa and Manuel Iglesias, arguing that a hypothesis was not a fact and expressing disagreement with the composition deduced. ${ }^{72}$ The lack of empirical data was most evident, more so if we bear in mind the role attributed to mantas.

\section{The Demographic Approach}

The other main approach in evaluating the impact of fumes on public health was linked to the study of demographic statistics. The contribution of experts in their attempt to solve the controversy was even more ambiguous in this case than in their interpretation of chemical facts. Most reports stated that the demographic data available lacked important details. For instance, they criticised the fact that the most recent figures on population and on morbidity and mortality were missing, and they only had data for the years previous to and immediately after the arrival of the British company. ${ }^{73}$ Data on immigration and emigration rates were also missing. ${ }^{74}$ For many authors, these were important drawbacks when trying to come to solid conclusions on the impact of fumes on public health. However, even though they only had a very poor response to their request for additional information, they all completed their reports with a straightforward conclusion, either positive or negative.

Statements on the information shortage that nevertheless did not stop experts taking a stance were heard throughout the years of the controversy. That said, the dominant position did evolve. It might be worth considering it briefly in order to evaluate the role of communication in expert assessment on risk. Before the 1888 Dictamen [statement], the Municipal Health Board found no proof of the impact of fumes on public health in demographic data, while the Provincial Health Board reached opposing conclusions almost simultaneously. In their 1888 Dictamen, the Royal Health Board took these two reports into account and developed a more detailed interpretation of the data in order to reach the same conclusions as the latter; the increase in fume emissions matched the negative evolution of demographic data. The Dictamen stressed that statistics showed there had been proportionally fewer births and more deaths since the increase in fume emissions.

When a year later the members of the Royal Academy of Medicine engaged in the controversy, they insisted on the lack of important data and compared statistics to a doubleedged sword which had been used to argue in favour or against. This was explicitly

72 Today we know that, under specific atmospheric conditions, the concentration of sulphur dioxide could be higher than that found at the emission point.

73 A. Fernández-Caro, Informe acerca de las calcinaciones de minerals de cobre de Junio de 1890 [Sobre las calcinaciones de la compañia minera de Riotinto], Biblioteca Real Academia Nacional de Medicina.

${ }^{74}$ Dictamen del Consejo Supremo de Sanidad del Reino, op. cit. (note 10). 
declared by academician Ángel Fernández Caro. However, in his own interpretation of demographic data he did not consider the previously raised arguments. Without responding to those emphasised by the Royal and Provincial Health Boards, he performed his own partial analysis of the statistics with a view to supporting the innocuous nature of the fumes. Fernández Caro did not consider, for instance, the mobility of the population, which had been a central argument in the above-mentioned reports. But he explicitly underlined that the Academy would be 'as impartial as Science' in the analysis. Ángel Pulido took on a very similar position while his main critics, the Provincial Health Board physicians, followed an approach more in line with previous reports. Criticism on the lack of information in the latter reports still highlighted the absence of migration figures and of statistical data concerning relevant years for comparing the populations' well-being before and after the increase in emissions. But this time it also considered the absence of data concerning municipalities that, though potentially exposed to fumes, were not as dependent on mining as Riotinto and Nerva. Santiago de la Villa and Manuel Iglesias, for instance, criticised the fact that the members of the Academy only received data from these two towns to discuss the position of the institution.

Despite considering data to be insufficient for the demographic analysis, experts built upon this data to conclude either way. One could argue that this contradictory attitude can be explained by the ever different speeds of science and policy. There is, however, an additional issue to be raised. The analysis of the demographic approaches is particularly interesting in order to identify a clear lack of continuity in the arguments in each report. The authors did not really accept participating in the controversy and taking a stand either supporting or rejecting previous arguments in a well-reasoned manner. This lack of continuity could be interpreted as the result of poor circulation of knowledge. However, as the more recent reports responded to earlier ones, the absence of continuity could be better explained within the context of the active construction of ignorance.

The reports written by medical experts between 1888 and 1890 were inconsistent in their arguments about the health impact of the fumes. They were nevertheless finalised, and they included several concluding remarks that led to law reform. The members of the Academy in 1890, in contrast, concluded that there was no proof of the negative impact of the fumes on public health. This was enough to ground the repeal of the 1888 ban on the teleras method. It is true, though, that in the final reports these conclusions were referred to as being provisional. The need to undertake more in situ studies was emphasised. But further research never came through, and legislation was built upon them, deeming them conclusive.

Finally, the conclusions of the Academy were clearly contrary to those of the Royal Health Council, and new information did not seem to explain the differences. The lack of relevant information was criticised at the time by Manuel Iglesias and Santiago de la Villa. They concluded that, since the information considered necessary and missing in the first reply by the Academy had not been gathered, the Academy should not change its position and thus avoid establishing acceptable doses. ${ }^{75}$ The selective circulation of knowledge and the active construction of ignorance to which we have referred when addressing the limited number of toxicants analysed; the exclusive focus on air and not rivers, inhabitants and not workers; the quoting of a short list of authors with questionable contributions; and

\footnotetext{
${ }^{75}$ M. Iglesias and S. de la Villa, Voto particular de los Sres. Iglesias y Villa en el expediente de las calcinaciones de Riotinto [Sobre las calcinaciones de la compañia minera de Riotinto], Biblioteca Real Academia Nacional de Medicina.
} 
a contradictory use of chemical and demographic analyses, and so on, are the only ways to explain the strong change in position.

\section{Explaining the Selective Circulation of Knowledge and the Construction of Ignorance}

My paper has highlighted a number of controversial issues related to expert assessment and its evolution in the late 1880s. Emphasis has been placed on medical experts, although knowledge and ignorance were also produced by additional stakeholders. In dealing with medical experts, we have focused on what they did and stated rather than on why they did so. However, in order to shed some light on the reasons that could explain their evolving attitude, I shall conclude by briefly tackling the evolution of the positions of other major stakeholders (such as state authorities and corporations). This wider approach takes us back to Sellers and Melling's framework of industrial hazard regimes. Although its promoters have mainly referred to regimes in the twentieth century, its use as an analytical category to study the Riotinto case could be interesting in order to qualify or complete the spatial change perceived by them. For instance, Sellers referred to a shift in priorities in the perception of industrial hazard from inside the factory to its vicinity, and finally to a detachment from the sites of production. ${ }^{76}$ In the case analysed in this paper, despite its occurrence in the late nineteenth century, the emphasis arguably reflected that of the second stage (roughly initiated in the 1920s) rather than that of the first one. This promising perspective will be further developed in a future paper.

From the publishing of the $1888 \mathrm{RD}$ to the requests made to the Royal Academy of Medicine by the end of 1889 , we can presume a complete change in the position of state authorities, as well as in the interests of important private economic players. Several key points may explain this change. In 1888 the dramatic ending of the demonstration of February 4 was probably perceived as a peak in the region's long and rising tension as regards the copper fumes. The government had to intervene in the conflict, and influential local landowners were arguably there to remind them of their responsibility. As already mentioned, these landowners - organised under the Liga Antihumista - included relevant local leaders who had possibly enhanced their visibility - and thus their lobbying power in such a dramatic situation.

Still, at that early stage, the mining industry was probably not particularly interested in maintaining or increasing its productivity, and thus it is possible that it had reduced its lobbying actions, for by 1887 Hyacinthe Secretan, the director of the Société Industrielle et Commercielle des Metaux, had launched a speculative operation aimed at controlling the world copper sector. He offered the main international corporations, such as the Rio Tinto Company Limited and Tharsis, a fixed rate - over market price - for all the copper they would produce in the following years. The only condition was to reduce production to so contribute to a rise in market value.

The two main copper mines of Huelva followed Secretan in his project but within two years the outcome was negative and the operation was dropped. This gave way to a very different context. The low-productivity strategy ceased and, additionally, important

${ }^{76}$ C. Sellers, 'Occupation, Environment and health: a history of changing perceptions and priorities', in P.D. Blanc and B. Dolan (eds), At Work in the World: Proceedings of the Fourth International Conference on the History of Occupational and Environmental Health (San Francisco, CA: University of California Medical Humanities Press, 2012). 
changes were made in the main company, in Riotinto. In a very successful move, the Rothschild family got involved in the Secretan operation and ended up as the main company shareholder. ${ }^{77}$ The arrival of the Rothschilds was important in many different ways. In relation to the active role of the company in lobbying against the calcination ban, one should take into account the family's great ability to intervene at the highest levels of Spanish political power. Since the opening of their branch in Spain, in 1835, they had been particularly good at recruiting relevant politicians and using major Spanish institutions for their own benefit. ${ }^{78}$ Their extraordinary power may well have been used between the 1888 Dictamen and the Academy Reports of June $1890 .^{79}$

In 1889 , the lobbying activities of the company were arguably different from those of the mining industry in 1887 mentioned above, both in relation to the interest that the corporation might have had, and as regards their ability or capacity for such an action. The position of the state was also seemingly different by the end of 1889 . This can be grasped, for instance, from the government's declared intention of reforming the RD of 1888, and the extremely focused request put forward to the Royal Academy of Medicine; for the state, the issue at stake was not whether or not copper fumes were noxious but, rather, the dose of one of its components (sulphurous acid) that could be deemed acceptable in the environment over long periods. The request clearly dismissed other potential risks considered in other countries.

From the Dictamen of 1888 to the reports in late 1889 and early 1890 , medical experts also changed positions. Although the scientific organ approached was different in each case, they were both supposed to represent the highest authority for medical matters, and several members were involved in both cases (e.g. Gabriel de la Puerta, a particularly active scholar), though voting for opposite measures. The parallel change in the positions of medical experts and state authorities could be explained through Sheila Jasanoff's Political Capture Model. ${ }^{80}$ The dependence on the state of the Royal Academy of Medicine, to which I have already referred in presenting the Academy as one of the "main governmental and judicial advisory organs', may have been a factor in the contradictory conclusions they reached (even with common data and, to some extent, with common experts). However, during my ongoing research on the assessment activities of the Royal Academy, my perspective has changed. Maybe the scholars at the Academy were not really 'captured' by the state. Perhaps they were conscious elements of it. Although in this specific controversy it may be slightly more difficult to argue in this sense (the main academicians involved were not yet politically engaged at the highest levels), one must not forget that in the trip to Riotinto the Academy members were accompanied by Spanish senators such as the Marquis of Trives and Manuel F. De Castro, and members of parliament such as José de Cárdenas, Ricardo Becerro de Bengoa, Eduardo Gullón, and the high-ranking army officers General Muñoz Vargas and General Salcedo.

\footnotetext{
${ }^{77}$ M.A. López-Morell, 'Los Rothschild en Río Tinto: Propiedad y control en el gigante minero', in A. Galán García (ed.), La presencia “inglesa” en Huelva: Entre la seducción y el abandono (Malaga: Universidad Internacional de Andalucía, 2011).

${ }^{78}$ Ibid.

79 The arrival of the Rothschild family was also important in implementing a progressive change in the corporate culture of the Rio Tinto Company. We mentioned that the company was, from its outset, not very innovative and basically dependent on the market know-how of the head office in London. The Rothschilds had a more positive attitude towards technical innovation, which consequently reduced dependence on old techniques such as the teleras method. Arguably, that did not happen until the mid-1890s, when Heinrich Doetsch, the main director on site, was sacked for imposing his odd and ruinous methods.

${ }^{80}$ S. Jasanoff, 'EPA's Regulation of Daminozide: Unscrambling the Messages of Risk', Science, Technology, \& Human Values, 12 (1987), 116-24.
} 
We must also take into account that the main lobbying players, the mining companies and the Liga antihumista, had direct connections with medical experts, at least in the 1890 assessment. The Royal Academy of Medicine received information from the latter, and the correspondence between the Academy and the Rio Tinto Company Limited is detailed and abundant. We know, for instance, that the Company offered the academicians funding for their trips to Riotinto, which may explain why, instead of the three members suggested by the Academy in 1889, more than fourteen members, participated. The influence of this direct relationship between medical experts and the corporations on the conclusions of the reports is not obvious, although we have strong evidence of the consequences of visiting the mines in a trip funded and co-ordinated by the mining company. We know, for instance, that the party was not taken to the Provincial Hospital; instead, they received statements from miners previously chosen by the company. ${ }^{81}$ We also know of the positive image given by important company figures such as the engineer Suwart, who invited the members of the commission to drink champagne, or by Bushell, the representative of the Rio Tinto Company in Madrid, who was described as impartial and agreeable. ${ }^{82}$

In conclusion, we must underline the fact that the medical experts developed their assessment in a highly charged environment in which arguably several strong stakeholders intervened, not only in establishing new regulations but also in defining risk. In this context, communication between local agents was necessarily fluent, although this was not so obvious when it came down to preserving the objective rhetoric of science. Industry, state and experts interacted, as well as engineers and medical experts, but their communication was usually rather opaque.

The paper has referred to the construction of ignorance at many different levels. Construction could be either passive or active and thus correspond to either type 2 or 3 in Proctor's taxonomy of ignorance. The extension at which these operated is difficult to ascertain, but both types were probably active in this controversy. In any case, what this paper has tried to render visible is the fact that the lack of continuity among the arguments raised by experts and, more generally, the above-mentioned opacity, stood as the perfect breeding ground for selective inattention or the simultaneous construction of ignorance and knowledge.

${ }^{81}$ Coto et al., op. cit. (note 16).

82 Pulido Fernández, Las calcinaciones de Huelva, op. cit. (note 15). 